\title{
VNÍMÁNÍ DRUHÉHO A DIALOG
}

\section{Maurice Merleau-Ponty}

Algoritmus a exaktní věda mluví o věcech, přičemž u toho, ke komu se obracejí, nepředpokládají ideálně nic více než znalost definic. Nechtějí jej svést, ani od něj neočekávají žádnou spoluúčast. V principu jej vodí za ruku od toho, co zná, k tomu, co si má osvojit, a mluva jej unáší, aniž by se přitom musel odchýlit od vnitřní evidence. Ovšem i v tomto řádu čistých významů a čistých znaků nový smysl povstává z toho starého jen díky proměně, která se odehrává mimo algoritmus a kterou algoritmus vždy předpokládá. Matematická pravda se může jevit jedině subjektu, pro nějž existují struktury, situace a perspektiva. Pokud to platí, máme ten nejpádnější důvod připustit, že ,̌rečové“ poznání vyvolává v daných významech proměny, které v nich nebyly obsaženy, a pokud ano, pak jedině tak, jako v sobě francouzský jazyk obsahuje francouzskou literaturu nebo jako jsou ve stylu spisovatele obsažena jeho budoucí díla. Máme tedy ten nejlepší důvod, abychom za vlastní funkci mluvy považovali její schopnost říkat vcelku vždy víc, než co říká slovo po slově, její schopnost předbíhat samu sebe. A to jak v případě, kdy navádím druhého k tomu, co vím a co on ještě nepochopil, tak v prrípadě, kdy přivádím sama sebe k tomu, co mám teprve pochopit.

Právě mluva je tím, co v literatuře či filosofii uskutečňuje tuto anticipaci, toto přesahování a překračování, co završuje tento násilný výkon, jímž formuji tvary a proměňuji postup, nechávám je stát se tím, čím jsou, měním je tak, že pak jsou samy sebou. Je ovšem zřejmé, že tak jako fyzická skutečnost nově načrtnuté čáry ještě není žádnou geometrickou konstrukcí, ani v uměních, která pracují s mluvou, nedostačuje samotná fyzická existence zvuků, písmena napsaná na papîre, ani faktická přítomnost těchto slov v souladu s jejich slovníkovým významem či takto hotových vět k utvoření smyslu. Výkon má svůj vnitřek a celý sled slov je pouze brázda, kterou za sebou zanechal a která vyznačuje jen body, kudy prošel. Avšak ustavené významy v sobě obsahují nový význam jedině v podobě stopy nebo horizontu. Nový význam se v ustavených

1 M. Merleau-Ponty, La perception d'autrui et le dialogue, in: týž, La prose du monde, Paris 2008, str. 182-203. - Pozn. překl. 
významech rozpozná, ovšem i když je převezme, zapomene je v tom, co v nich bylo dílčího a naivního. Vrhá jen chvilkové záblesky do hloubi minulého vědění, dotýká se jej jen z odstupu. Minulé poznání se dovolává nového významu a ten mu nazpět odpovídá a přitakává. Sled slov, který tvoří knihu, je spojen do jediného pohybu jednou a toutéž sotva postižitelnou odchylkou od obvyklého úzu, trváním na určité výstř̌ednosti. Při vstupu do místnosti můžeme vidět, že se něco změnilo, aniž bychom svedli říci co. Když vstupuji do knihy, cítím, že se všechna slova změnila, ale nedokážu říci v čem. Smysl knihy je řečový díky neobvyklému úzu, který je určen jistou a setrvalou odchylkou, již zprvu nejsme schopni vysvětlit. Všechny útvary našeho světa se změní, protože jeden z nich byl vyrván ze své prosté existence, aby zastupoval všechny ostatní, aby se stal klíčem k tomuto světu či jeho stylem, všeobecným prostředkem k jeho interpretaci. Často se mluvilo o karteziánských „myšlenkách“, které se zatoulaly již ke svatému Augustinovi, ba k samotnému Aristotelovi, ale vedly tam pouze mdlý život bez budoucnosti. Jako by se všechen význam nějaké myšlenky, celý duch určité pravdy zakládal na jejím reliéfu, na jejím okolí a nasvícení. Augustin narazil na cogito, Descartes v Dioptrice na okazionalismus a Balzac se jednou strefil do Giradouxova stylu - jen si toho nevšimli. Descartes tak musí vystoupit po Augustinovi, Malebranche po Descartovi a Giaradoux po Balzacovi. Vrcholem pravdy tedy i nadále zůstává perspektiva. Tím chceme říci, že vedle pravdy adekvace (což by byla pravda algoritmu, pokud by se kdy dokázal oddělit od myslícího života, jímž je nesen) existuje pravda, která tkví v prosvítání, v protínání a přejímání. Na této pravdě se podílíme nikoli tím, že myslíme tutéž věc, ale tím, že se každého z nás svým způsobem týká a že nás zasahuje. Spisovatel také jistě mluví o světě a o věcech, ovšem nepředstírá, že se u všech čtenářů obrací $\mathrm{k}$ jedinému čistému duchu. Obrací se u nich právě k jejich způsobu, jímž se zabydlují ve světě, tváří v tvář životu a smrti. Chápe se jich tam, kde jsou, a mezi předměty, události a lidi vkládá rozestupy, roviny a nasvícení. Dotýká se v nich jejich nejtajnější vnitřní výbavy, doráží na jejich základní vazby ke světu a jejich hlubokou zaujatost proměňuje v prostředek pravdy. Algoritmus mluví o věcech a nádavkem se dotýká i lidí. Spis mluví k lidem a skrze ně dosahuje pravdy. Tomuto přesahování věcí směrem $\mathrm{k}$ jejich smyslu, této diskontinuitě vědění, která dosahuje svého vrcholu v mluvě, porozumíme jedině, když ji pochopíme jako přesahování mě do druhého a druhého do mě...

Chceme-li tedy porozumět nejvlastnější moci mluvy, vstupme pozvolna do dialogu, ale ze všeho nejdříve do tichého vztahu s druhým. 
Málo se zdůrazňuje, že druhý se k nám nikdy neobrací svou tváří. Dokonce ani tehdy, když se v největším zápalu diskuze ocitám „tváří v tvář“ svému protivníkovi, se onen záměr, jenž se mě dotýká, nenachází ani ve vzteklé grimase tváře, ani v onom hlase, který si ke mně razí cestu prostorem. Můj protivník se nikdy nenachází na zcela určitém místě: jeho hlas, gestikulace a vyjadřovací návyky jsou pouhými efekty, jakousi inscenací či ceremonií. Jejich inscenátor je tak dobře maskován, že jsem velmi překvapen, když jej mé odpovědi zasáhnou: ten skvělý řečník nedá slovo dohromady, vzmůže se jen na povzdechy, drmolení, cosi jako známky inteligence. Člověk musí věřit, že tam někdo byl. Ale kde? Nikoli v tom př́liš zvučném hlase, ani v té tváři poznamenané vráskami jako opotřebovaný předmět. A zajisté ani za tímto ústrojím: dobře vím, že tu není nic jiného než „temnota napěchovaná orgány““.2 Tělo druhého je přede mnou - ale co se druhého týče, vede zvláštní existenci, existenci mezi mnou, který myslí, a tímto tělem; anebo spíše blízko mě, po mém boku, je jakoby replikou mne samého, mým bludným dvojníkem. Neobjevuje se přímo v mém okolí, ale spíše jím obchází. Druhý je nečekanou odpovědí, kterou dostávám odkudsi odjinud. Jako kdyby věci nějakým zázrakem začaly vyjadřovat mé myšlenky - stále by byly myslící a hovořící pro mě, protože věci jsou věci a já jsem já. V mých očích je druhý tudíž vždy na okraji toho, co vidím a slyším, je na mé straně, po mém boku či za mnou - nenachází se v tom místě, které můj pohled drtí a zbavuje jakéhokoli „vnitřku“. Druhý je vždycky druhým já. Je jako dvojník, kterého nemocný̉ pocit'uje vždy po svém boku a jenž se mu podobá jako bratr, jehož však nemocný nemůže zachytit pohledem, aniž by tím způsobil, že se rozptýlí: očividně je jen prodloužením jeho samého navenek, jelikož i trocha pozornosti stačí, aby dvojník zmizel. Já a druhý jsme jako dva téměř soustředné kruhy, které se od sebe liší jen mírným a tajuplným posunem. Tato spřízněnost je možná právě tím, co nám umožní pochopit vztah k druhému; ten zůstává neuchopitelný, pokud zkouším přistupovat k druhému tváří v tváŕ, z neschůdné strany.

2 Obrat „ténèbres bourées d'organes“ pochází od P. Valéryho, Introduction à la méthode de Léonard de Vinci (1919). Merleau-Ponty tento obrat opakovaně využívá ve svých úvahách o těle, viz týž, Viditelné a neviditelné, přel. M. Petř́íček, Praha 2004, str. 141; viz také týž, Fenomenologie vnímání, přel. Jakub Čapek, Praha 2013, str. 397. - Pozn. přek1.

3 Merleau-Ponty zde naráží na případy osob trpících heautoskopií (halucinací sebe samého), viz M. Merleau-Ponty, Fenomenologie vnímání, str. 195 a 257 n. Pozn. překl. 
Druhý nicméně není mnou, a odsud nutně dospíváme k opačnému pohledu. Vytvářím druhého $\mathrm{k}$ obrazu svému, ale jak pro mě může existovat obraz mne samého? Cožpak se nerozprostírám až na konec světa, nemám snad já sám stejný rozsah jako všechno, co mohu vidět, slyšet, čemu mohu rozumět, co mohu předstírat? Jak by mohl existovat pohled vnější vůči této totalitě, kterou jsem já? Odkud by bylo možné takový pohled zaujmout? Leč přesně k tomu dojde, když se mi zjeví druhý. $\mathrm{K}$ tomu nekonečnu, kterým jsem byl, se přidává něco dalšího; vyrůstá odnož, rozdvojuji se, rodí se ze mne druhý. Je tvořen mou vlastní podstatou, a přece už to nejsem já. Jak je to možné? Jak se může ono já myslím vystěhovat někam mimo mne, když jsem to já? Pohledy, kterými jsem bloudil po světě, jako když slepec ot'ukává předměty svou holí, někdo chytil za druhý konec a obrátil je proti mně, aby se na oplátku dotkly mě. Již se nespokojuji s tím, že vnímám: vnímám, že jsem vnímán, a že jsem vnímán jakožto vnímající, vnímající samu tuto skutečnost, že jsem vnímán... Nestačí pouze říct, že odted’ obývám jiné tělo: tím bychom dospěli jen k druhému mně samému, k druhému obydlí pro mě. Ale je tu nějaké já, které je jiné, které sídlí jinde a připravuje mě o mé ústřední postavení, ačkoliv se podle všeho může stávat oním já jen skrze filiaci se mnou. Role subjektu a toho, co je jím viděno, se proměňují a obracejí. Myslel jsem, že tomu, co vidím, dávám význam věci viděné, a náhle se jedna z těch věcí tomuto stavu vymkne, představení si samo opatřuje diváka, kterým nejsem já a který je mou kopií. Jak je to možné? Jak mohu vidět něco, co se samo jme vidět?

Již jsme řekli, že nikdy nelze pochopit, jak by se druhý mohl zjevovat před námi; před námi se nachází jen předmět. Je nutné si uvědomit, že takto problém nestojí. Problém je pochopit, jak se rozdvojuji, jak přicházím o své ústřední postavení. Zkušenost s druhým je vždy zkušeností s replikou mne samotného, s replikou mně samému. Řešení je třeba hledat v této podivné filiaci, kvůli které je druhý vůči mně vždy druhotný, a to i když mu dávám přednost před sebou samým a obětuji se pro něj. Ono podivuhodné spojení s druhým se utváří hluboko uvnitř mě samého; záhada druhého není nic jiného než záhada mne samého. Možnost, že se ze mne narodí druhý divák tohoto světa, není vyloučena; já to naopak umožňuji, tedy alespoň pokud beru v úvahu své vlastní paradoxy. Co mě činí jedinečným, totiž mé základní určení, že vnímám sebe samého, má paradoxně tendenci se rozšiřovat; právě proto, že jsem totalitou, jsem schopen přivést druhého na svět a shledat, že jsem jím omezen. Nebot' zázrak vnímání druhého spočívá především v tom, že cokoliv, co kdy může v mých očích platit za jsoucí, je takové pouze proto, že se dostává, 
at' přímo či nepřímo, do mého pole, že se objevuje v rejstříku mé zkušenosti a vstupuje do mého světa. Takže můžeme říci, že vše, co je pravdivé, je mé, ale také že vše, co je mé, je pravdivé. Jako svědka se přitom dovolává nejen mě samotného s mými omezeními, ale též druhého $\mathrm{X}$, a v mezním případě i absolutního diváka - pokud by tedy druhý nebo absolutní divák byli myslitelní. Vše je ve mně připraveno přijmout tato svědectví. Otázkou nicméně zůstává, jak budou kdy moci proniknout až do mě samého. Bude to opět proto, že mé je mé a moje pole pro mě zůstává universálním prostředím bytí.

Dívám se na muže, který bez hnutí spí a najednou se probouzí. Otevírá oči, natáhne se po svém spadlém klobouku ležícím vedle něj a zvedne ho, aby se chránil před sluncem. Co mě nakonec přesvědčuje, že mé slunce je také jeho sluncem, že je vidí a vnímá stejně jako já a že konec konců jsme dva, kdo vnímáme svět, je právě to, co mi na první pohled brání uchopit druhého. A sice to, že jeho tělo patří mezi mé předměty, je jedním z nich a vystupuje v mém světě. Jakmile se člověk spící mezi mými předměty $\mathrm{k}$ nim začne obracet svými pohyby a používat je, nemohu ani na okamžik pochybovat, že svět, k němuž se obrací, je skutečně tentýž svět, který vnímám já. Vnímá-li něco, pak to musí být můj vlastní svět, jelikož právě v něm se rodí. Ale proč by jej měl vnímat, jak si vůbec mohu představit, že je toho schopen? Pokud to, co bude vnímat, je nezbytně to samé, co vnímám i já, pak přinejmenším jeho vnímání světa, které nyní předpokládám, nemá místo $\mathrm{v}$ mém světě. Ale kam ho umístit? Není v tom těle, které není nic jiného než tkáně, krev a kosti. Není ani na cestě od tohoto těla $\mathrm{k}$ věcem, protože na této cestě jsou jedině další věci, nebo světelné paprsky a vlnění, a přelétavých obrazů Epikúrových jsme se přece vzdali už dávno. Co se týká „ducha“, to jsem já, a tak do něj nemohu vložit toto jiné vnímání světa. Druhý se tedy nenachází ve věcech, není ve svém těle, a nejsem to já. Nemůžeme ho umístit nikam a také ho nikam neumist'ujeme, ani do bytí v sobě, ani do bytí pro sebe, kterým jsem já. Není pro něj místo jinde než v mém poli, ale toto místo tu pro něj je připravené přinejmenším od té doby, co jsem začal vnímat. Od první chvíle, kdy jsem využil své tělo ke zkoumání světa, jsem věděl, že tento tělesný vztah ke světu může být zobecněn. Mezi mnou a jsoucím, které si vyhradilo právo na jiné vnímání téhož jsoucna, se tehdy utvořil nepatrný rozestup. Druhý se nenachází nikde ve jsoucnu, do mého vnímání se vkrádá zezadu. Zkušenost, kterou tvořím na základě svého uchopení světa, mi umožňuje rozpoznat v něm jinou zkušenost a vnímat druhé já, avšak jen pod podmínkou, že uvnitř mého světa se rýsuje gesto podobné mému. V okamžiku, kdy se muž probouzí na slunci a napřahuje ruku po 
svém klobouku, se mezi sluncem, které mě pálí a nutí mě přimhouřit oči, a gestem, které odtamtud $\mathrm{z}$ dálky přináší úlevu mé únavě, mezi tamtím rozpáleným čelem a gestem ochrany, jehož se u mne dovolává, utvořilo pouto, aniž bych musel o něčem rozhodovat. A třebaže nejsem nikdy schopen skutečně prožít zkušenost slunečního žáru, jak jej zakusil ten druhý, zraňující působení světa, jak je cítím na svém těle, poraňuje vše, co je mu vystaveno stejně jako já, a obzvlášt' tělo, které se tomu začíná bránit. Zkušenost slunečního žáru oživila dosud nehybného spáče a má se $\mathrm{k}$ jeho gestům jako důvod jejich existence.

Svět přiléhá $\mathrm{k}$ mému tělu jako Nessova tunika, a proto neexistuje pouze pro mě, ale pro cokoli v něm, co se k němu obrací významuplným gestem. Je zde jakási universalita smyslového vnímání - a na ní spočívá naše ztotožnění, zobecnění mého těla, vnímání druhého. Vnímám chování vnořená do stejného světa, do něhož jsem vnořen i já, nebot' svět, který vnímám, s sebou unáší i moji tělesnost. Mé vnímání je dopad světa na mne a uchopení světa mými gesty. Takže mezi věcmi, k nimž směřjí gesta spáče, a gesty samotnými existuje nejen vnější vztah jednoho předmětu k druhému, ale též dopad, jakoby od světa ke mně, a uchopení, jakoby ode mě ke světu, nebot' jak věci, tak gesta tvoří součást mého pole. A ptáme-li se dále, co mě přimělo připsat roli vtěleného subjektu, jež náleží mně, i „druhým“ a proč se mi pohyby druhého vůbec jeví jako gesta, proč automat ožívá a objevuje se druhý, musíme nakonec odpovědět, že je tomu tak proto, že ani tělo druhého, ani předměty, na něž se zaměřuje, pro mě nikdy nebyly pouhými předměty, nýbrž nacházejí se uvnitř mého pole a mého světa, a od počátku tedy jde o variace tohoto základního vztahu (i o věcech říkám, že jsou k sobě „obrácené čelem“ anebo ,zády“). Jedno pole nevylučuje druhé pole tak, jako jeden akt absolutního vědomí, například rozhodnutí, vylučuje druhý. Samo od sebe má naopak tendenci se zmnožovat, nebot' je bránou, kterou jsem jakožto tělo ,vystaven” světu, a nemá onu absolutní hutnost čistého vědomí, která pro toto vědomí činí jakékoli jiné vědomí nemožné, a protože je samo obecné, chápe se jen jako jedno mezi sobě podobnými... To znamená, že druzí by pro mě neexistovali, ani jako druhé mysli, kdybych já neměl tělo a kdyby oni neměli tělo, které jim umožňuje vklouznout do mého pole, zmnožit je zevnitř a jevit se mi jako vydaní napospas stejnému světu a uchopující stejný svět jako já. Vše, co je pro mě, je mé a má pro mě hodnotu jsoucna jedině tehdy, začlení-li se do mého pole. To nebrání, ale naopak umožňuje, aby se mi druhý zjevil, nebot' můj vztah k sobě samému je již zobecněním. Proto se druhý, jak jsme už uvedli na začátku, vždy začleňuje do skloubení světa a nás samých, proto je vždy mimo 
věci a spíše po našem boku než ve věcech. To je dáno tím, že druhý je zobecněné já a má své místo nikoli v objektivním prostoru - v němž, jak správně konstatoval Descartes, mysl nenajdeme -, nýbrž v této antropologické „lokalitě“, v nejasném prostředí, kde se zcela nenuceně pohybuje nereflektované vnímání. Druhý se nachází vždy na okraji reflexe, nelze jej konstituovat, je vždy již konstituovaný: druhého nacházíme tak, jako nacházíme vlastní tělo. Jakmile druhému pohlédneme do tváře, redukujeme jej na neškodnou věc, od níž si lze držet odstup. Druhý existuje za námi stejně jako věci, jež nabývají absolutní nezávislost na okraji našeho vizuálního pole. Často a z dobrého důvodu se protestovalo proti zdánlivému řešení psychologů, kteří ve snaze porozumět např́iklad tomu, jak pro nás ožívá př́íroda nebo jak existují druhé mysli, vykládali věc tak, že mluvili o „projekci“ nás samých do věcí. To ponechává otázku nezodpovězenou, nebot' stále nevíme, jaké motivy přímo ve vzezření vnějších věcí nás k této projekci vyzývají. Nevíme ani, jak mohou věci „dávat znamení" mysli. My zde neuvažujeme o takovéto psychologické projekci, která překračuje naši zkušenost s námi samými a s tělem směrem k takovému vnějšímu světu, který by s ní neměl žádný podstatný vztah. Naopak se pokoušíme vzkřísit tělesnou vazbu ke světu a k druhému, která není jen nahodilým vnějším případkem čistého poznávajícího subjektu (vždyt' jak by jej do sebe mohl přijmout?), ani jen jedním z mnoha „obsahů“ zkušenosti, ale je naším prvotním včleněním do světa a do toho, co je pravdivé.

Možná jsme nyní schopni správně pochopit, jaký výkon pro nás představuje mluva, jak prodlužuje a proměňuje onen němý vztah k druhému. V jistém smyslu, slova druhého naše ticho neprolamují. Nemohou nám poskytnout nic víc, než co nám poskytují jeho gesta. Pochopit, jak pro nás mohou slova poskládaná do výpovědí znamenat něco jiného než naši vlastní myšlenku, představuje stejnou obtíž jako pochopit, jak nám mohou pohyby těla uspořádané $\mathrm{v}$ gesta či v chování zpřítomňovat někoho jiného než nás - jak můžeme v těchto představeních nalézt něco jiného než to, co jsme tam sami vložili. Řešení je v obou případech stejné. Co se týče našeho němého vztahu k druhému, spočívá v pochopení, že naše vnímavost vůči světu, naše synchronní vazba ke světu - to jest naše tělo, což je teze předpokládaná všemi našimi zkušenostmi - naši existenci zbavuje hutnosti absolutního a jedinečného aktu. Tím se $\mathrm{z}$ „tělesnosti“ stává přenositelný význam, je umožněna „společná situace“, a nakonec i vnímání druhého my. A třebaže druhého nevnímáme $v$ absolutnu jeho skutečné existence, vnímáme jej přinejmenším v jejím obecném náčrtu, který nám je přístupný. Stejně tak je tomu v případě onoho zvláštního 
gesta, kterým je mluva. Zde řešení spočívá v uznání, že ve zkušenosti dialogu se promluva druhého přichází dotknout našich významů v nás, zatímco naše slova se ve druhém dotknou jeho významů, jak dosvědčují odpovědi. Zasahujeme jeden do druhého, jelikož náležíme ke stejnému kulturnímu světu, a především ke stejnému jazyku, a jelikož výrazové akty mé i druhého závisí na témže založení. ${ }^{4}$ Toto „obecné“ užívání mluvy však předpokládá užívání jiné, základnější - stejně jako má společná existence s mými bližními předpokládá, že jsem je nejprve jako své bližní rozpoznal. Předpokládá, jinak řečeno, že se mé pole ukázalo jako nevyčerpatelný zdroj bytí, a to nejen bytí pro mě, ale též bytí pro druhého. Naše společná přináležitost $\mathrm{k}$ témuž světu je založena na tom, že moje zkušenost je původně zkušeností bytí, a stejně tak je naše přináležitost $\mathrm{k}$ jednomu společnému jazyku, či dokonce $\mathrm{k}$ společnému řečovému universu založena na původním vztahu mezi mnou a mojí mluvou. Právě díky tomu se mluva stává dimenzí bytí, na níž se může podílet také $X$.

Díky tomuto vztahu se druhé já může stát druhým i mnou v mnohem zásadnějším smyslu. Společný jazyk, kterým mluvíme, je něco jako anonymní tělesnost, kterou sdílím s ostatními organismy. Pouhé užívání tohoto jazyka, stejně jako ustavené formy chování, jichž jsem činitelem a svědkem, mi dává druhého jen v obecnosti, neurčitě rozptýleného v mém poli, tedy v antropologickém nebo kulturní prostoru. Druhý zde vystupuje takříkajíc jako jedinec určitého druhu, celkově spíš jako pojem než přítomnost. Avšak výrazový výkon, a zvláště mluva, je-li zachycen ve stavu zrodu, ustavuje společnou situaci, která již není pouze společenstvím v bytí, ale společenstvím v jednání. ${ }^{5}$ Právě zde se skutečně

4 Výraz „založení“ (institution, Stiftung) se stal ústředním pojmem Merleau-Pontyho myšlení 50. let. Například v přednáškách z let 1954-1955 jej vymezuje slovy: „Založením jsme zde ... rozuměli ony události ve zkušenosti, které tuto zkušenost obdařují trvalými dimenzemi, ve vztahu k nimž celá další série jiných zkušeností nabude smysl a bude tvořit myslitelnou souslednost nebo historii.“ M. Merleau-Ponty,Založenía podstata,vyd.J.Fulka - A. Tesková,Praha 2011,str. 171. Pozn. překl.

5 [Poznámka po straně rukopisu:] Je tomu tak z toho důvodu, že se mluva nezaměřuje na přirozený svět, ale na svět spontaneity - na svět nikoli smyslový. Čím se na této úrovni stává neviditelný druhý? Zůstává neviditelný: po mém boku, za mnou a tak dále. Ovšem nikoli proto, že sdílíme stejnou prehistorii, ale proto, že sdílíme touž mluvu. Tato mluva je obecně vzato stejná jako druhý: neuchopitelná a netematizovatelná, a jako taková i obecná, nikoli individuální. Jako kdyby však individuálnost smyslového vnímání sublimovala až do podoby komunikace. Právě takovou mluvu máme na mysli: mluvu, která tedy nespočívá pouze na obecnosti. Má být nad-objektivní, nad-významová. V takové mluvě se stírá rozdíl mezi jednotlivým bytím a významem. Mizí protiklad mezi mým jazykem a mým dílem, jedinečným 
odehrává komunikace a ticho se zdá být prolomeno. Rozdíl mezi „přirozeným“ gestem (pokud lze vůbec nalézt nějaké gesto, jež nepředpokládá ani nevytváří určitou významovou stavbu) a mluvou spočívá v tom, že „přirozené" gesto ukazuje předměty, které jsou našim smyslům beztak již dány, zatímco úkolem výrazového gesta, a zejména mluvy, je odhalovat nejen vztahy mezi již danými členy, ale také samotné členy těchto vztahů.

Sedimentované kulturní vrstvy, které poskytují našim gestům a slovům společný a samozřjejmý základ, byly nutně těmito gesty a slovy nejprve utvořeny - a stačí trocha únavy, aby se tato základnější komunikace přerušila. Takovouto komunikaci již nevysvětlíme tím, že přináležíme ke stejnému světu, nebot' právě po této přináležitosti se ptáme a tu je třeba vyložit. Můžeme nanejvýš říci, že naše zakořenění v téže zemi a zkušenost jedné a téže přírody nás $\mathrm{k}$ tomuto podniku vybízejí: nemohou mu zaručit úspěch, ani jej samy uskutečnit.

V okamžiku, kdy byl vyjádřen první „lidský“ význam, se rozběhl podnik, jenž překračuje naši společnou prehistorii, ačkoliv je pokračováním jejího pohybu. Právě tato dobyvačná mluva nás zajímá, to ona umožňuje ustanovenou mluvu, tedy jazyk. Tato mluva sama má poučovat o svém smyslu jak toho, kdo mluví, tak toho, kdo naslouchá. Nestačí, že ohlašuje smysl chápaný již jedním i druhým. Je třeba, aby tomuto smyslu vdechla bytí, a proto je pro ni podstatné, že překračuje samu sebe jakožto gesto. Je gestem, které se jako takové ruší a překračuje směrem ke smyslu. Tato mluva předchází všem ustaveným jazykům, je oporou jejich života, a na oplátku je těmito jazyky přiváděna k existenci. A jakmile jsou založeny společné významy, přenáší své úsilí dál. Její výkon je proto nutné pojímat mimo veškerý již založený význam - jako jedinečný akt, kterým si mluvící člověk opatřuje posluchače a také kulturu, jež bude oběma společná.

Takovouto mluvu ovšem nelze nikde spatřit. Stejně jako druhého, nemohu ani mluvu nikam umístit. Stejně jako druhý je spíše po mém boku než ve věcech, ale nemohu ani říct, že by byla „ve mně“, nebot' je stejně tak i ,v posluchači“. Je tím, co je mi nejvlastnější, mojí tvůrčí schopností, a přesto je tím vším jen proto, aby z toho tvořila smysl a sdělovala ho. Druhý, který naslouchá a rozumí, se ke mně připojuje v tom, v čem jsem nejvíce jedinečný: jako kdyby zmiňovaná universalita smyslového

a universálním. Jiné je naroubováno na stejné. Mluvení je nerozlišitelné od poslouchání, to speak od to be spoken to. Pokračujme... A zároveň, násilná povaha této mluvy. Nad-označující. Sympatie totalit. 
vnímání konečně přestala být universalitou pro mě a přerostla $\mathrm{v}$ universalitu uznanou. Slova druhého nebo moje slova v něm se neomezují na to, že v posluchači jako struny rozechvívají soustavu osvojených významů či oživují určitou vzpomínku. Pronášená slova mě musí navádět směrem k významu, který nepatří ani mně, ani mluvčímu. Když vnímám organismus, jak se gesty obrací k svému okolí, začínám jej vnímat jako vnímající protějšek, nebot' vnitřní uspořádání jeho gest je stejné jako vnitřní uspořádání mých chování a jeho gesta ke mně promlouvají o mém vlastním vztahu ke světu. Stejně tak když mluvím k druhému a poslouchám ho, se to, co slyším, vkládá do intervalů v tom, co říkám. Má mluva je napřič protínána mluvou druhého, slyším se v něm a on mluví ve mně. Mezi to speak to a to be spoken to zde není žádný rozdíl. Tento neredukovatelný fakt v sobě ukrývá každé zápolení o výraz a může nám ho zpřítomnit literární vyjádření, pokud bychom na něj snad chtěli zapomenout.

Jelikož mluva bez ustání obnovuje zprostředkující spojení mezi stejným a jiným, nutí nás neustále si ověřovat, že význam vyvstává jen skrze pohyb, zprvu násilný, který přesahuje všechny významy. Můj vztah ke knize vychází z jednoduché obeznámenosti se slovy našeho jazyka, s myšlenkami, které tvoří součást naší výbavy, stejně jako mé vnímání druhého je v prvním přiblížení vnímáním gest či chování „lidského druhu“. Ovšem pokud mě kniha skutečně něčemu naučí, pokud je druhý skutečně druhým, musím být $\mathrm{v}$ jistém okamžiku překvapen a dezorientován. Musíme se setkávat již nikoli v tom, v čem jsme si podobní, ale také $\mathrm{v}$ tom, $\mathrm{v}$ čem se lišíme. To předpokládá jistou proměnu mne samého, jakož i druhého. Naše rozdíly již nemohou být jen jako neproniknutelné kvality, ale musí se stát smyslem. Při vnímání druhého to nastává, pokud jiný organismus, místo toho, aby „se choval“ jako já, využívá věci mého světa stylem, který se mi nejprve zdá záhadný, avšak který se mi od počátku alespoň jeví jako styl. Odpovídá totiž jistým možnostem, kterými byly věci mého světa obklopeny. Stejně tak když čtu, musí mi autorův záměr v určité chvíli uniknout, musí se skrýt. Vracím se proto nazpět a čtu s novou chutí, anebo pokračuji dále a později mi nějaké št’astné slovo umožní, abych se chytil, navede mě ke středu nového významu a já do něj vstoupím skrze tu z jeho „stránek“, která je již součástí mojí zkušenosti.

Racionalita ani soulad jednotlivých myslí nevyžadují, abychom ke stejné myšlence všichni došli stejnou cestou nebo aby bylo možné uzavřít významy do definice. Vyžadují pouze, aby každá zkušenost obsahovala spouštěče pro všechny myšlenky a aby „myšlenky“ byly nějak 
uspořádány. Toto dvojité tvrzení je tvrzením určitého světa. Zde se již nejedná o jednotu, která se stvrzuje universalitou smyslového vnímání. Té jednoty, o které hovoříme, se spíše dovoláváme, než že bychom ji konstatovali, protože je téměr neviditelná a vybudovaná na systému našich znaků. Proto ji nazýváme kulturní svět. Mluvou pak nazýváme svou moc využít jisté příhodně uspořádané věci - černou a bílou, zvuk hlasu, pohyby ruky - tak, aby zdůrazňovaly, rozlišovaly, dobývaly a shromažd’ovaly významy bloudící na horizontu smyslového světa. Anebo také svou moc vdechnout do neproniknutelnosti smyslového takové prázdno, které je projasní, avšak které se stejně jako vzduch vehnaný do láhve neobejde bez nějaké substanciální reality. Naše vnímání ostatních živých bytostí tedy vposled závisí na evidenci smyslově vnímaného světa, který je vystaven jiným, a přesto srozumitelným chováním. Stejně tak je vnímání skutečného alter ego založeno na předpokladu, že jeho promluva má ve chvíli, kdy jí rozumíme, a především tehdy, když se před námi skrývá a hrozí, že se stane nesmyslem, moc préetvořit nás k obrazu svému a otevřít nás jinému smyslu. Tuto moc nemá promlouvající druhý přede mnou jakožto vědomí: vědomí dovede ve věcech nalézt jen to, co do nich samo vložilo. Může se přede mnou prosadit jako mně rovný, nakolik i já sám jsem mluvou, to jest, nakolik jsem schopen nechat se vést pohybem promluvy k novému stavu poznání.

Mezi mnou jakožto mluvou a druhým jakožto mluvou, nebo obecněji mnou jakožto výrazem a druhým jakožto výrazem, již nestojí alternativa, která ze vztahu mezi dvěma vědomími dělá vztah soupeření. Aktivní nejsem jen tehdy, když hovořím, ale i když předbíhám svou mluvu v posluchači; když poslouchám, nejsem pasivní, ale mluvím podle toho, co říká druhý. Mluvit neznamená jen být iniciativní, poslouchat neznamená jen snášet inciativu druhého. Vždyt' coby promlouvající subjekty konec konců pokračujeme, vynakládáme opětovně stejné úsilí starší než my, na něž jsme jeden i druhý naroubováni a které je ukazováním a děním pravdy. Ř́íkáme, že co je pravdivé, bylo vždycky pravdivé, ovšem to je jen matoucí vyjádření toho, že všechny dřívější výrazy ožívají a nachází své místo ve výrazu přítomném. Díky tomu můžeme, pokud o to stojíme, zpětně číst přítomný výraz ve výrazech dřívějších, či lépe znovunalézat výrazy dřívější ve výrazu prrítomném. Základ pravdy není mimo čas, ale spočívá $v$ otevřenosti každého momentu poznání pro ty, kdo se ho znovu chopí a promění jej v jeho smyslu. To, co nazýváme mluvou, není nic jiného než toto předjímání a opětovné uchopování, toto dotýkání z odstupu, které nelze chápat ve smyslu kontemplace, toto hluboké spolčení času se sebou samým. 
Živoucí vztah mluvících subjektů je zakrýván skutečností, že za model mluvy považujeme vždy výpověd’ nebo větu oznamovací. Činíme tak proto, že všechno ostatní kromě výpovědí se nám jeví jako pouhé žvatlání a nerozum. To ale znamená zapomenout na všechno to tiché, nevyslovené a nevyjádřené, co vstupuje do vědeckých výpovědí, co se podílí na určení jejich smyslu a co právě skýtá budoucí vědě její výzkumné pole. Znamená to zapomenout, že existuje literární výraz, v němž máme odhalovat právě to, co bychom mohli označit jako „nad-význam“ a co je třeba odlišit od ne-smyslu. Zakládáme-li význam na mluvě, chceme tím říci, že významu náleží jevit se vždy jen jako pokračování již dříve započaté promluvy, jako zasvěcení do již ustaveného jazyka. Zdá se, že význam předchází texty, v nichž se stává zjevným. Nikoliv ale proto, že by texty nechávaly na zem sestoupit ideje, které již před tím existovaly v inteligibilním nebi, nebo v Př́rodě, anebo ve Věcech, nýbrž proto, že žádná mluva není fakticky jen výrazem pro toto, ale vždy se od počátku dává jako zlomek nějaké universální promluvy a ohlašuje určitý interpretační systém. Zato afatici, mají-li vést s někým rozhovor nebo psát na čistý list papíru, potřebují předem zvolené „opěrné body“ či nějaké vodítko, předkreslenou linku nebo jen inkoustovou skvrnu na papíre, aby je vytrhla ze závratě z prázdnoty a dovolila jim začít. A můžeme-li proti sobě postavit nadbytek a nedostatek podnětů, nachází se na opačném pólu mluvy Mallarmé, který je prázdnou stránkou fascinován, nebot' by chtěl vyjádřit celek, donekonečna odkládá psaní Knihy a jako své dílo nám zanechává texty, které mu vytrhla z rukou jen souhra okolností - texty, kterým dala pokradmu, a naštěstí, vzniknout jeho slabost.

Spisovatel, kterému se daří, ani mluvící člověk nejsou tak moc či tak málo uvědomělí. Než začnou mluvit, neptají se, zda je mluva možná, ani se nepozastavují nad utrpením řeči spočívajícím v tom, že chceme-li říci vůbec něco, nemůžeme říci vše. Blaženě se usazují ve stínu tohoto velikého stromu, nahlas pokračují ve vnitřním monologu a jejich myšlení klíčí v mluvě. Aniž o to usilovali, jsou druhými pochopeni a stávají se druhými, když vyslovují to, co je jim nejvíce vlastní. Přebývají sami u sebe a necítí se být odloučeni od druhých, a protože jsou naprosto přesvědčeni, že co se jim zdá evidentní, je i pravdivé, prostě to poví. Přecházejí po ledovcových mostech, aniž by si povšimli jejich křehkosti, a až na samou mez využívají té nesmírné síly, jež náleží každému vědomí, považuje-li se za koextenzivní s tím, co je pravdivé: síly přesvědčovat o tom druhé a vstupovat do jejich tajných zákoutí.

$\mathrm{V}$ jistém smyslu je každý pro sebe totalitou světa, a když je o tom přesvědčen, tak se to ve stavu zvláštní milosti stane pravdou: nebot' pak 
mluví a druzí mu rozumějí - a soukromá totalita se sbratří s totalitou společenskou. V mluvě se uskutečňuje nemožný soulad dvou soupeřících totalit. Nikoliv proto, že by nám dala vstoupit do nás samých a umožnila nalézt jakousi jedinou mysl, na níž bychom se podíleli, nýbrž proto, že se nás mluva týká, nepřímo nás zasahuje, svádí nás a uchvacuje, proměňuje nás v druhého a druhého v nás, stírá hranice mezi vlastním a ne-vlastním a ruší alternativu mezi tím, co pro mě má smysl a co je pro mě ne-smysl, mezi mnou jakožto subjektem a druhým jakožto objektem.

At' se jistí lidé klidně snaží zamezit této spontánní moci ve vměšování, at' proti ní staví svoji přísnost a nedostatek dobré vůle: však jejich ticho bude zase ukončeno slovy, a to právem. Není žádné ticho, které by bylo čistou pozorností a které by poté, co vznešeně započalo, dostálo samo sobě. Jak říkal Maurice Blanchot, Rimbaud vykročil za mlu$\mathrm{vu}$ - a skončil u dalšího psaní. Psal pak ovšem ty dopisy z Habeše, které se beze stopy humoru dovolávají počestného blahobytu, rodiny a veřejné úcty... Vždy tedy přijímáme pohyb výrazu; i když ho odmítneme, jsme na něj dál odkázáni. Jak tedy nakonec pojmenovat tuto moc, jíž jsme zaslíbeni a která z nás, at' chceme nebo ne, vydobývá významy? Jistě to není nějaký bůh, nebot' její výkon závisí na nás; a není to ani zlotřilý démon, nebot' přináší pravdu. Není to ani „lidská situace“ - anebo je-li „lidská“, pak v tom smyslu, že člověk ničí obecnost druhu a otevírá druhým přístup do své nejzazší jedinečnosti. Ono víceznačné gesto, které z jedinečného učiní něco universálního a z našeho života smysl, nejlépe označíme tak, že je nazveme mluvou či spontaneitou.

Přeložili

Jakub Čapek, Daniela Matysová a Jaroslav Větrovský 